\title{
Influence of dietary protein content on the chemico-physical profile of dry-cured hams produced by pigs of two breeds
}

\author{
Giuseppe Carcò ${ }^{1}$, Stefano Schiavon $\mathbb{1}^{1 *}{ }^{*}$, Ernestina Casiraghi ${ }^{2}$, Silvia Grassi ${ }^{2}$, Enrico Sturaro ${ }^{1}$, \\ Mirco Dalla Bona ${ }^{1}$, Enrico Novelli ${ }^{3}$ \& Luigi Gallo ${ }^{1}$
}

The use of low-protein (LP) feeds is a good strategy to reduce the environmental release of $\mathrm{N}$ compounds, but their influence on the quality of the products must be considered. This study explored the influence of LP diet and two pig breeds (BR) with different lean growth ability on the quality traits of dry-cured hams. We analysed 40 left dry-cured hams from pigs of two BR [Duroc-Danbred crosses (Danbred) and Duroc $\times$ Large White crosses (Anas)] fed either conventional (147 to $132 \mathrm{~g} /$ $\mathrm{kg}$, crude protein) or LP diet. The LP had a crude protein content reduced by $20 \%$ with respect to the conventional. The differences in ham quality resulting from protein reduction were small, with a decrease of the protein and an increase of the lipid content of the ham slice in Anas, but not in Danbred $(B R \times$ Diet interaction; $P=0.043$ ). Therefore, the use of $L P$ would be feasible and sustainable, without detrimental effects on products. It was found the pig genotypes with different potentials for lean growth may affect the initial ham weight, fat cover and seasoning losses of hams, but they appear to affect little other chemical, physical and textural quality traits of the dry-cured hams.

Dry-cured ham is a traditional product in many Mediterranean areas ${ }^{1}$. At present, European Union quality control schemes recognise over 30 types of dry-cured ham, roughly half of which are classified Protected Designation of Origin (PDO) and half Protected Geographical Indication ${ }^{2}$.

It is generally agreed that ham quality depends on a combination of factors, including pig genotype, feeding and management practices, and curing procedures ${ }^{3-5}$. Producers of Italian hams with PDO, for example, must comply with specific requirements regarding pig genotype and feeding practices ${ }^{6,7}$. Previous studies on the effects of pig genotype and feed composition on the quality of raw hams ${ }^{8,9}$ have assumed the weight, back-fat cover and marbling of the raw material to be highly correlated with the final quality of the dry-cured hams ${ }^{10,11}$. When processing is standardised, it is reasonable to assume that the quality of the final product largely depends on the characteristics of the ham before curing ${ }^{7}$.

The use of low protein and low amino acid feeds (LP) has recently emerged as one of the best strategies to reduce the environmental release of $\mathrm{N}$ compounds from pig farms. In many experiments, LP diets have been found to increase fat cover thickness and intramuscular fat ${ }^{12-14}$. Greater fat cover thickness reduces the water losses during ripening, and this would exert positive effects on the final quality of the product ${ }^{15,16}$.

Heavy pig production in Italy has largely relied on the use of Large White, Landrace and Duroc breeds and their crosses, still considered as "traditional" genotypes. However, in the last decades is increasing the use of other breeds, and commercial hybrids, characterized by better farm performance and leaner carcasses ${ }^{7}$, such the Danish Duroc (Danbred) breed. Although a lean pig genotype is assumed to negatively affect the quality of dry-cured hams ${ }^{6}$, studies investigating the relationships between the genetic origin of pigs and the qualitative attributes of dry-cured hams are still lacking.

The aim of this study was to investigate the influence of LP diets on the characteristics of dry-cured hams obtained from two breeds of pigs with different lean growth potential.

${ }^{1}$ University of Padova, Department of Agronomy, Food, Natural Resources, Animals and Environment, Legnaro, PD, 35020, Italy. ${ }^{2}$ University of Milano, Department of Food, Environmental and Nutritional Sciences (DeFENS), Milano, 20133, Italy. ${ }^{3}$ University of Padova, Department of Comparative Biomedicine and Food Science, Legnaro, PD, 35020, Italy. *email: stefano.schiavon@unipd.it 


\begin{tabular}{|c|c|c|c|c|c|c|c|c|c|}
\hline & \multicolumn{4}{|c|}{ Diet (D) } & \multicolumn{4}{|c|}{ Breed (BR) } & \multirow{2}{*}{\begin{tabular}{|l|}
$\mathrm{D} \times \mathrm{BR}$ \\
$P$
\end{tabular}} \\
\hline & CONV & LP & SEM & $P$ & Anas & Danbred & SEM & $P$ & \\
\hline $\begin{array}{l}\text { Raw ham fat } \\
\text { thickness }^{\mathrm{a}}, \mathrm{mm}\end{array}$ & 19.8 & 21.9 & 1.21 & 0.23 & 23.7 & 18.1 & 1.20 & 0.003 & 0.72 \\
\hline \multicolumn{10}{|l|}{ Ham weight, kg } \\
\hline raw (trimmed) & 14.7 & 14.8 & 0.21 & 0.70 & 14.4 & 15.2 & 0.21 & 0.008 & 0.36 \\
\hline after salting & 14.4 & 14.4 & 0.18 & 0.92 & 14.0 & 14.8 & 0.18 & 0.004 & 0.29 \\
\hline after seasoning & 10.1 & 10.1 & 0.15 & 0.72 & 9.92 & 10.3 & 0.15 & 0.08 & 0.37 \\
\hline after deboning & 7.59 & 7.65 & 0.13 & 0.72 & 7.52 & 7.72 & 0.13 & 0.29 & 0.66 \\
\hline \multicolumn{10}{|c|}{ Weight losses, kg } \\
\hline after salting $^{\mathrm{b}}$ & 0.37 & 0.46 & 0.04 & 0.15 & 0.39 & 0.43 & 0.04 & 0.48 & 0.97 \\
\hline after seasoning & 4.65 & 4.69 & 0.10 & 0.77 & 4.44 & 4.89 & 0.10 & 0.002 & 0.55 \\
\hline after deboning $^{\mathrm{c}}$ & 7.13 & 7.18 & 0.13 & 0.78 & 6.84 & 7.47 & 0.13 & 0.001 & 0.29 \\
\hline \multicolumn{10}{|l|}{ Weight losses, \% } \\
\hline after salting & 2.45 & 3.03 & 0.26 & 0.12 & 2.70 & 2.78 & 0.26 & 0.82 & 0.86 \\
\hline after seasoning & 31.6 & 31.7 & 0.42 & 0.96 & 30.9 & 32.2 & 0.42 & 0.041 & 0.99 \\
\hline after deboning & 48.4 & 48.4 & 0.49 & 0.93 & 47.6 & 49.2 & 0.49 & 0.030 & 0.56 \\
\hline
\end{tabular}

Table 1. Weights and losses of dry-cured hams obtained from pigs of different breeds (BR) and sex fed on

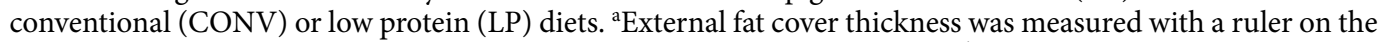
Biceps femoris muscle below the head of the femur of the fresh trimmed ham. ${ }^{b}$ Weight losses after salting were $0.47 \mathrm{~kg}$ for barrows and $0.35 \mathrm{~kg}$ for gilts $(P=0.047 ; \mathrm{SEM}=0.003)$. ${ }^{\mathrm{c}}$ Weight losses after deboning were $6.97 \mathrm{~kg}$ for barrows and $7.33 \mathrm{~kg}$ for gilts $(P=0.048$; $\mathrm{SEM}=0.13)$.

\section{Results}

Weight changes. Diet and the $\mathrm{BR} \times$ diet interaction had no influence on the weights and weight losses of the hams $(P>0.05$, Table 1$)$. Hams from barrows exhibited greater weight loss at salting $(+34.2 \%, P=0.047)$ but lower losses at deboning $(-5.2 \%, P=0.048)$ than those from gilts (data not in table). At the arrival at the ham factory, immediately after trimming, the trimmed Danbred hams had nearly $24 \%$ less fat cover thickness $(P=0.003)$ than the Anas hams, but were heavier both before salting $(5.6 \%, P=0.008)$ and after $(5.7 \%, P=0.004)$. However, they also had greater weight losses at seasoning $(10.1 \%, P=0.002)$ and deboning $(9.3 \%, P=0.001)$, so that, despite their greater initial weight, they had similar weights to the Anas hams at the end of seasoning and deboning $(P=0.08$ and 0.29 , respectively).

Chemical composition. The hams from the Danbred pigs had a greater protein content $(2.5 \%, P=0.039)$ than those from Anas, and the hams from pigs fed the LP diet had a greater lipid content $(+9.8 \%, P=0.05)$ and a lower protein content $(-3.1 \%, P=0.003)$ and protein:lipid ratio $(-10.5 \%, P=0.008)$ than those from pigs fed conventional (CONV) diets (Table 2$)$. However, diet interacted with BR for lipids $(P=0.045$, Fig. 1$)$, as the dietary protein reduction decreased the protein content $(P=0.006)$ and increased the lipid content $(P=0.07)$ and the protein:lipid ratio $(P<0.001)$ of the Anas hams compared with little variation $(P>0.05)$ in the Danbred hams. Breed and diet had no influence $(P>0.05)$ on the salt content of the lean part of the ham. The salt content was negatively correlated with water activity and the proteolysis index, and positively correlated with seasoning losses (Fig. 2), but there was only weak correlation between cover fat thickness of the fresh ham and the salt content (Fig. 3).

As expected, removing from the slice the subcutaneous fat increased water $(10.4 \%, P<0.001)$, protein $(4.7 \%$; $P<0.001)$ and ash $(10.9 \%, P<0.001)$ content of the lean part of the slice and the protein:lipid ratio $(68.9 \%$, $P<0.001)$ and decreased lipid content $(-39.7 \%, P<0.001)$ with respect to the whole slice. However, a BR $\times$ tissue interaction was found for protein $(P=0.038)$ and lipid $(P=0.003)$ contents and for the protein:lipid ratio $(P=0.004)$. In fact, the whole slice from the Danbred hams had a $4.4 \%$ greater protein content $(P=0.001)$ and a 9.1\% lower fat content $(P=0.054)$ than Anas hams, but the composition of the lean part was similar in the hams from the two breeds $(P>0.05$, Fig. 4$)$.

Physical and textural traits. Diet and breed had little or no influence on $\mathrm{pH}$, water activity, colour attributes and textural traits $(P>0.05$, Table 3$)$. However, almost all traits were significantly influenced by muscle $(P<0.001)$. Namely, the shear force was markedly greater in the semimembranosus muscle than in the biceps femoris. The hardness and chewiness values of the biceps femoris and the quadriceps femoris were almost twice those of the semitendinosus and semimembranosus muscles $(P<0.001)$. The biceps femoris had the greatest adhesiveness and the lowest cohesiveness.

Fatty acid composition. The reduction in the dietary crude protein (CP) level had no significant influence on the FA composition of the ham tissues $(P>0.05$, Table 4$)$. The intramuscular and the subcutaneous FA profiles differed greatly, the former having a greater polyunsaturated FA content $(P<0.001)$, mainly due to the proportions of 18:2 cis-9, cis-12 $(P<0.001)$ and 20:4 cis-5, cis-8, cis-11, cis-14, and a lower monounsaturated FA content $(P<0.001)$, due to 18:1 cis $-9(P<0.001)$. The FA profiles of the ham tissues were influenced by breed. The Danbred hams had a greater polyunsaturated FA content $(P<0.001)$, mainly because of the 18:2 cis-9, cis-12 


\begin{tabular}{|c|c|c|c|c|c|c|c|c|c|c|c|c|c|}
\hline & \multicolumn{4}{|c|}{ Diet (D) } & \multicolumn{4}{|c|}{ Breed (BR) } & \multicolumn{2}{|c|}{ Tissue (T) } & \multirow[b]{2}{*}{ SEM } & \multirow[b]{2}{*}{$P$} & \multirow{2}{*}{\begin{tabular}{|l|}
$\mathrm{BR} \times \mathrm{D}$ \\
$P$ \\
\end{tabular}} \\
\hline & CONV & LP & SEM & $P$ & Anas & Danbred & SEM & $P$ & $\begin{array}{l}\text { Slice, } \\
\text { whole }\end{array}$ & $\begin{array}{l}\text { Slice, lean } \\
\text { part }\end{array}$ & & & \\
\hline \multicolumn{14}{|c|}{ Chemical composition, $\mathrm{g} / \mathrm{kg}$} \\
\hline Water & 507 & 505 & 3.3 & 0.67 & 508 & 504 & 3.3 & 0.39 & 481 & 531 & 3.2 & $<0.001$ & 0.06 \\
\hline Protein $^{c}$ & 289 & 280 & 2.1 & 0.003 & 281 & 288 & 2.1 & 0.039 & 278 & 291 & 1.7 & $<0.001$ & 0.36 \\
\hline Ash & 70.6 & 69.3 & 1.2 & 0.48 & 68.6 & 71.3 & 1.2 & 0.12 & 66.3 & 73.5 & 0.9 & $<0.001$ & 0.49 \\
\hline Lipid $^{\mathrm{d}}$ & 133 & 146 & 4.5 & 0.05 & 142 & 137 & 4.5 & 0.44 & 174 & 105 & 4.2 & $<0.001$ & $0.045^{\mathrm{b}}$ \\
\hline Protein:Lipid $^{e}$ & 2.37 & 2.12 & 0.06 & 0.008 & 2.25 & 2.25 & 0.06 & 0.99 & 1.67 & 2.82 & 0.06 & $<0.001$ & $0.023^{\mathrm{b}}$ \\
\hline Soluble protein ${ }^{\mathrm{f}}$ & 81.5 & 78.9 & 1.0 & 0.07 & 80.3 & 80.2 & 1.0 & 0.98 & - & - & - & - & 0.54 \\
\hline Salt $^{\mathrm{f}}$ & 53.1 & 51.9 & 0.9 & 0.35 & 51.6 & 53.4 & 0.9 & 0.18 & - & - & - & - & 0.32 \\
\hline Proteolysis index ${ }^{f}$ & 0.277 & 0.275 & 0.004 & 0.68 & 0.276 & 0.276 & 0.004 & 0.92 & - & - & - & - & 0.69 \\
\hline \multicolumn{14}{|l|}{ TBARS, $\mathrm{mg} / \mathrm{kgg}^{\mathrm{g}}$} \\
\hline Biceps femoris muscle & 0.54 & 0.55 & 0.03 & 0.85 & 0.56 & 0.52 & 0.03 & 0.44 & - & - & - & - & 0.12 \\
\hline subcutaneous fat & 0.56 & 0.48 & 0.03 & 0.07 & 0.52 & 0.53 & 0.03 & 0.77 & - & - & - & - & 0.11 \\
\hline
\end{tabular}

Table 2. Chemical characteristics of the dry-cured hams obtained from pigs of different breeds and sex ${ }^{\mathrm{a}}$ fed on conventional (CONV) or low protein (LP) diets. ${ }^{a}$ The fixed effect of sex was not significant. ${ }^{b}$ The least square means of the $\mathrm{BR} \times \mathrm{D}$ interaction are given in Fig. $2^{\mathrm{c}}$ The $P$ value of the $\mathrm{BR} \times \mathrm{T}$ interaction was 0.038 (Fig. 5). ${ }^{\mathrm{d}}$ The $P$ value of the $\mathrm{BR} \times \mathrm{T}$ interaction was 0.003 (Fig. 5 ). ${ }^{\mathrm{e}}$ The $P$ value of the $\mathrm{BR} \times \mathrm{T}$ interaction was 0.004 (Fig. 5). ${ }^{\mathrm{f}}$ Measured on the lean part of the slice ${ }^{\mathrm{g} T B A R S}$ : thiobarbituric acid reactive substances.
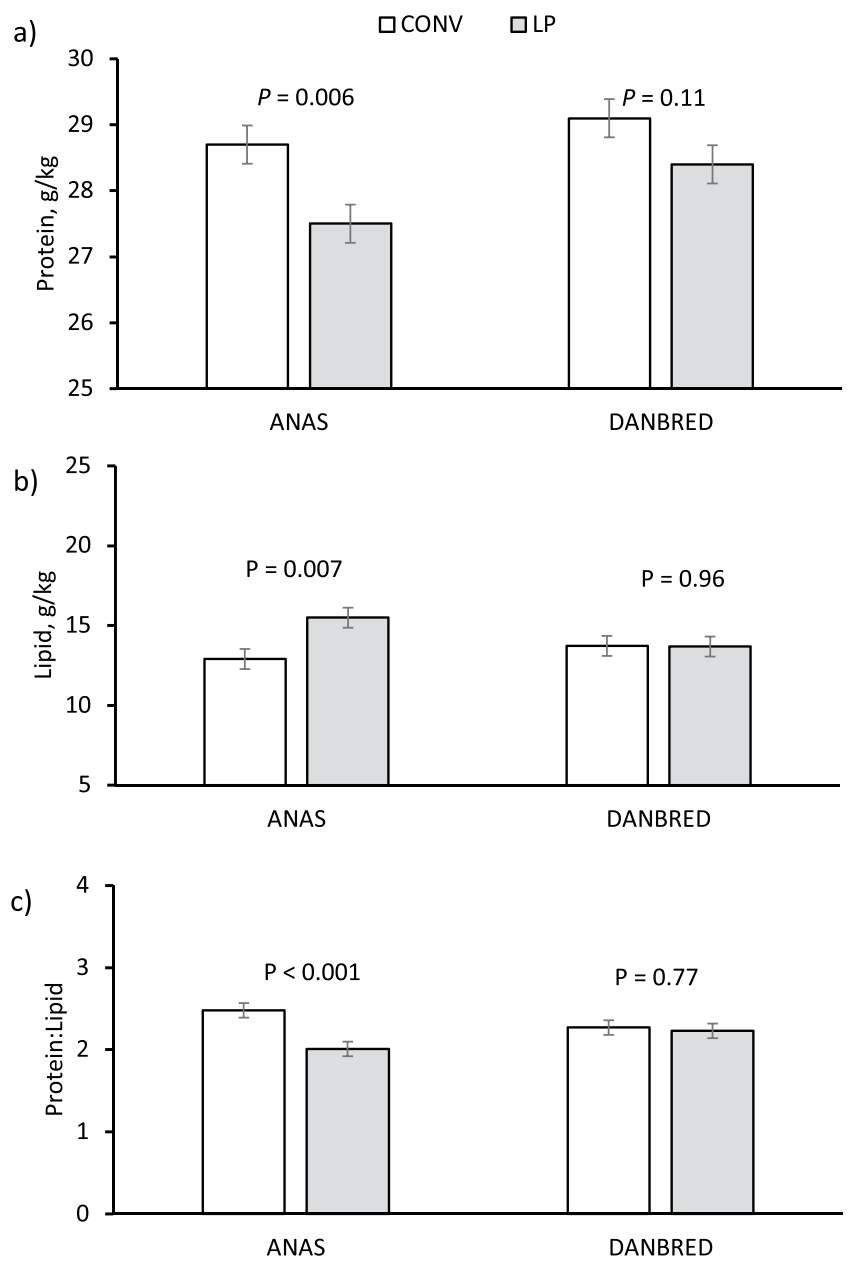

Figure 1. Influence of the genetic line $\times$ diet interaction on: (a) the lipid content $(P=0.045)$, and (b) the protein:lipid ratio $(P=0.023)$ of the dry-cured hams. Contrasts were run to evidence differences between conventional and low-protein diets within genetic line $(n=10$, vertical bars indicate standard errors of the means). 

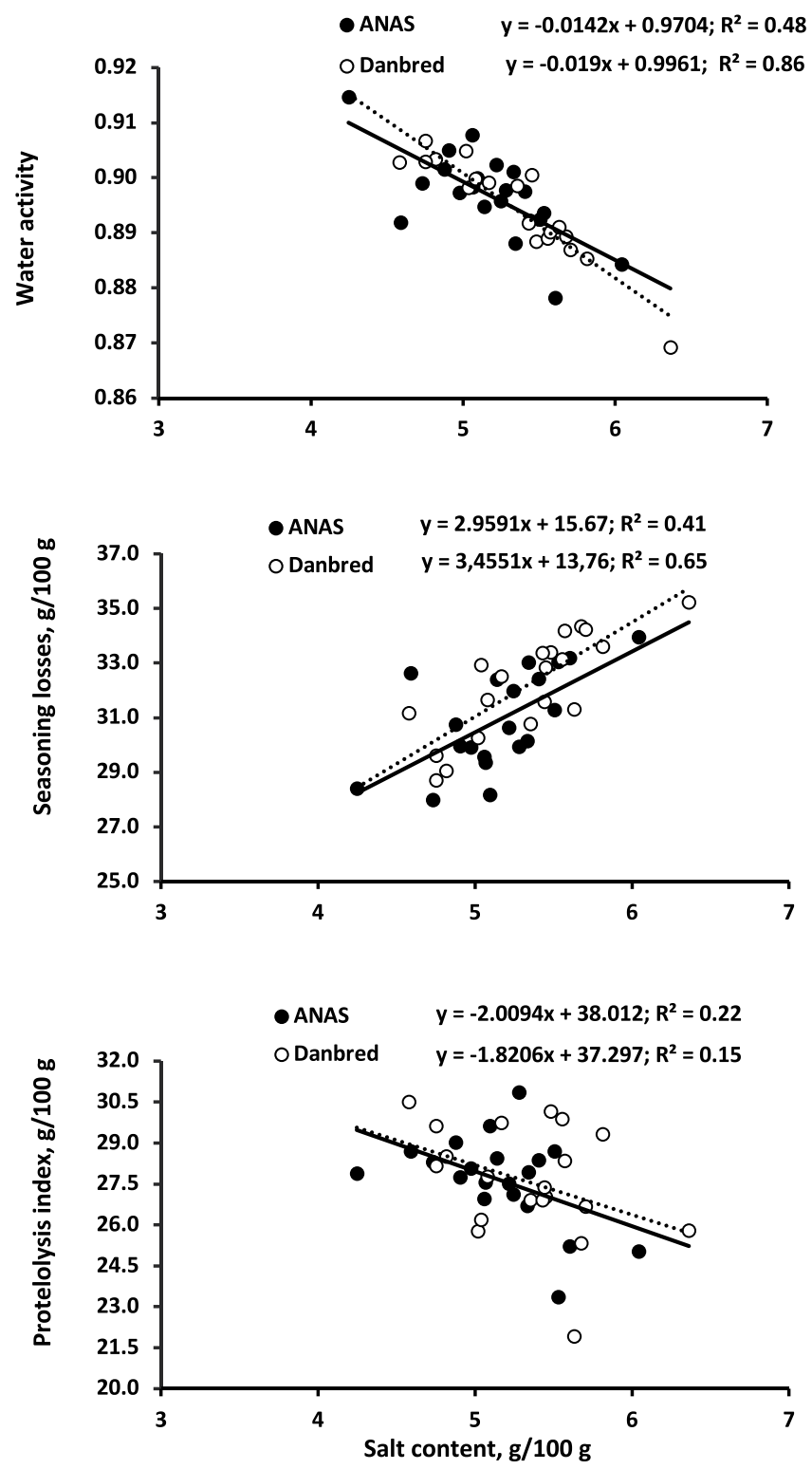

Figure 2. Relationships between salt content and (a) water activity in the lean part of the ham slice, (b) seasoning and deboning losses, and (c) proteolysis index.

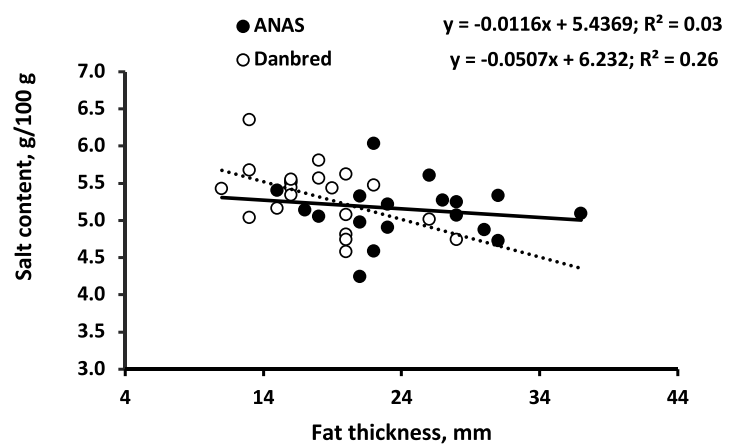

Figure 3. Relationship between the subcutaneous fat depth of the raw ham and the salt content of the lean part of the slice. 

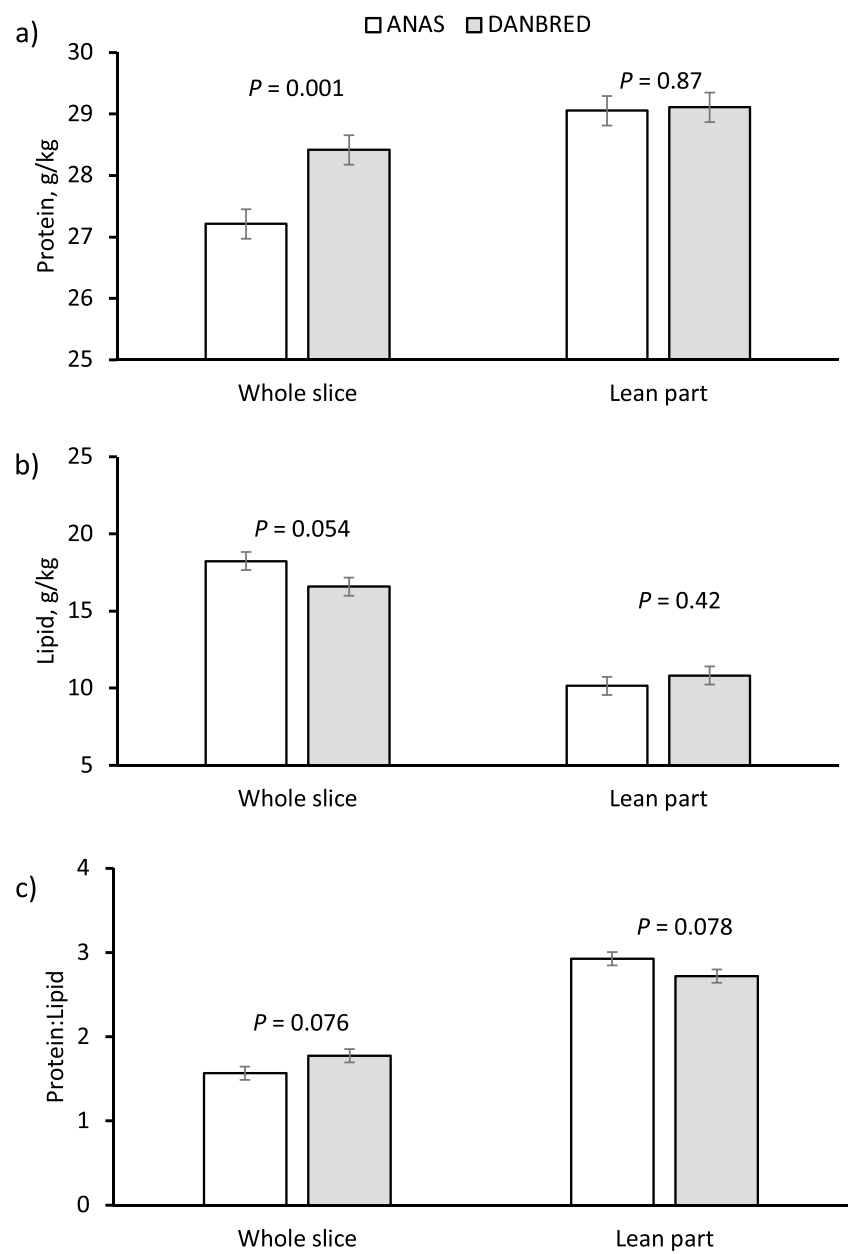

Figure 4. Influence of the genetic line $\times$ tissue interaction on: (a) the protein content $(P=0.038)$, (b) the lipid content $(P=0.003)$, and $(c)$ the protein:lipid ratio $(P=0.004)$ of the whole and the lean part of the ham slice. Contrasts evidenced differences between GLs in the constituent contents of the whole and of the lean part of the slice ( $n=10$, vertical bars indicate SE of the means).

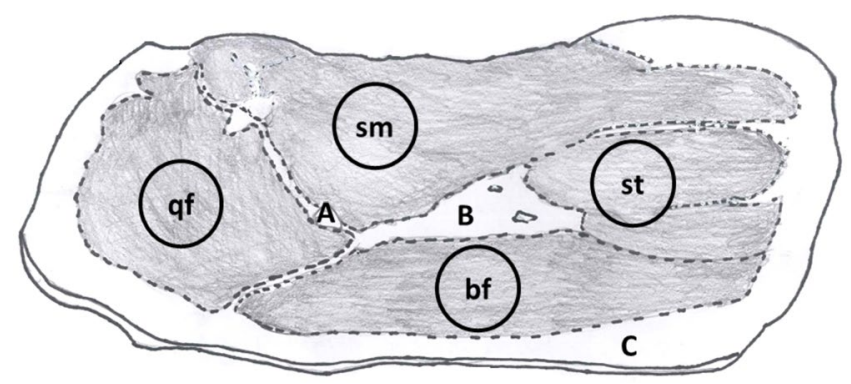

Figure 5. Slice of deboned dry-cured ham. bf: biceps femoris; qf: quadriceps femoris; sm: semimembranosus muscle; st: semitendinosus muscle. (a) Bone area; (b) Fatty area; (c) Subcutaneous fat.

content $(P<0.001)$, and slightly lower amounts of some other monounsaturated and saturated FA compared with Anas hams.

\section{Discussion}

Feed characteristics and breeds are considered important sources of variation of the quality of dry-cured hams ${ }^{4,6}$. Most of the literature in this area has focussed on the influence of genetics and feeding on the quality of the raw ham ${ }^{8,11,15}$, whereas their effects on the characteristics of the dry-cured ham have been less investigated ${ }^{17,18}$. Furthermore, few experiments have compared the quality traits of dry-cured hams obtained from pigs of different breeds and fed on different diets under the same rearing conditions ${ }^{6}$. 


\begin{tabular}{|c|c|c|c|c|c|c|c|c|c|c|c|c|c|c|c|}
\hline & \multicolumn{4}{|c|}{ Diet (D) } & \multicolumn{4}{|c|}{ Breed (BR) } & \multicolumn{6}{|c|}{ Tissue $(\mathrm{T})^{2}$} & \multirow{2}{*}{$\begin{array}{l}\mathrm{BR} \times \mathrm{D} \\
P\end{array}$} \\
\hline & CONV & LP & SEM & $P$ & Anas & Danbred & SEM & $P$ & BF & QF & SM & ST & SEM & $P$ & \\
\hline $\mathrm{pH}$ & 5.49 & 5.52 & 0.01 & 0.07 & 5.51 & 5.50 & 0.01 & 0.39 & $5.51^{\mathrm{bc}}$ & $5.53^{c}$ & $5.50^{\mathrm{b}}$ & $5.48^{\mathrm{a}}$ & 0.01 & $<0.001$ & 0.49 \\
\hline Water activity $^{3}$ & 0.90 & 0.90 & 0.002 & 0.76 & 0.90 & 0.89 & 0.002 & 0.36 & - & - & - & - & - & - & 0.84 \\
\hline \multicolumn{16}{|l|}{ Colour: } \\
\hline Lightness $\left(\mathrm{L}^{*}\right)$ & 37.5 & 37.3 & 0.29 & 0.64 & 37.7 & 37.2 & 0.29 & 0.30 & $38.1^{c}$ & $35.6^{\mathrm{b}}$ & $33.5^{\mathrm{a}}$ & $42.7^{\mathrm{d}}$ & 0.34 & $<0.001$ & 0.37 \\
\hline Green-red $\left(a^{*}\right)$ & 7.00 & 6.92 & 0.18 & 0.78 & 7.05 & 6.87 & 0.18 & 0.46 & $6.86^{\mathrm{b}}$ & $8.28^{\mathrm{d}}$ & $7.53^{c}$ & $5.18^{\mathrm{a}}$ & 0.19 & $<0.001$ & 0.77 \\
\hline Blue-yellow $\left(b^{*}\right)$ & 8.24 & 8.30 & 0.12 & 0.75 & 8.26 & 8.28 & 0.12 & 0.92 & $7.47^{\mathrm{a}}$ & $8.61^{\mathrm{b}}$ & $7.02^{\mathrm{a}}$ & $9.97^{c}$ & 0.14 & $<0.001$ & 0.80 \\
\hline \multicolumn{16}{|l|}{ Texture: } \\
\hline Shear force, $\mathrm{N}$ & 32.8 & 33.6 & 1.10 & 0.59 & 33.0 & 33.4 & 1.10 & 0.81 & $21.4^{\mathrm{a}}$ & $36.2^{\mathrm{b}}$ & $42.5^{\mathrm{c}}$ & $32.7^{\mathrm{b}}$ & 1.56 & $<0.001$ & 0.22 \\
\hline Hardness (30\%), N & 20.7 & 19.3 & 1.09 & 0.36 & 19.1 & 21.0 & 1.09 & 0.22 & $26.3^{\mathrm{b}}$ & $24.0^{\mathrm{b}}$ & $13.6^{\mathrm{a}}$ & $16.2^{\mathrm{a}}$ & 1.07 & $<0.001$ & 0.30 \\
\hline Adhesiveness, $\mathrm{N} \times \mathrm{s}$ & -1.73 & -1.73 & 0.08 & 1.00 & -1.81 & -1.66 & 0.08 & 0.20 & $-2.00^{c}$ & $-1.48^{\mathrm{a}}$ & $-1.84^{\mathrm{bc}}$ & $-1.62^{\mathrm{ab}}$ & 0.09 & $<0.001$ & 0.88 \\
\hline Cohesiveness & 0.54 & 0.55 & 0.01 & 0.25 & 0.55 & 0.54 & 0.01 & 0.56 & $0.53^{\mathrm{a}}$ & $0.60^{\mathrm{b}}$ & $0.53^{\mathrm{a}}$ & $0.52^{\mathrm{a}}$ & 0.01 & $<0.001$ & 0.51 \\
\hline Springiness & 0.73 & 0.73 & 0.01 & 0.81 & 0.73 & 0.73 & 0.01 & 0.81 & 0.74 & 0.72 & 0.72 & 0.72 & 0.01 & 0.34 & 0.10 \\
\hline Chewiness, N & 8.42 & 7.92 & 0.52 & 0.50 & 7.76 & 8.58 & 0.52 & 0.27 & $10.6^{\mathrm{b}}$ & $10.6^{\mathrm{b}}$ & $5.33^{\mathrm{a}}$ & $6.18^{\mathrm{a}}$ & 0.54 & $<0.001$ & 0.65 \\
\hline
\end{tabular}

Table 3. Physical characteristics of the different muscles of dry-cured hams obtained from pigs of different breeds and sex ${ }^{1}$ fed on conventional (CONV) or low protein (LP) diets. ${ }^{1}$ The fixed effect of sex was not significant. ${ }^{2}$ BF: Biceps femoris; QF: Quadriceps femoris; SM: Semimembranosus muscle; ST: Semitendinosus muscle. ${ }^{3}$ Measured on square samples $(15 \times 15 \mathrm{~mm})$ taken from close to the Biceps femoris muscle.

The use of LP diets is an effective strategy for reducing the environmental release of $\mathrm{N}$ and its potential polluting effects ${ }^{19}$. Previous experiments in the Italian heavy pig industry have found that diets formulated to achieve a reduction from 146 to $117 \mathrm{~g} / \mathrm{kg}$ of CP and from 7.3 to $5.8 \mathrm{~g} / \mathrm{kg}$ of total lysine in early finishing (90 to $130 \mathrm{~kg}$ BW) and 133 to $108 \mathrm{~g} / \mathrm{kg}$ of CP and 5.7 to $4.7 \mathrm{~g} / \mathrm{kg}$ of total lysine in late finishing (130 to $165 \mathrm{~kg} \mathrm{BW}$ ) had negligible influence on growth performance ${ }^{20}$, weight of carcass and primary cuts, and yields of the dressed hams ${ }^{21}$, but greatly reduced $\mathrm{N}$ excretion ${ }^{20}$. Interestingly, Gallo et al..$^{15}$ found that reducing the dietary $\mathrm{CP}$ content from 14 to $11 \%$ increased the subcutaneous fat thickness, decreased linoleic and polyunsaturated fatty acid in fat depots, and reduced seasoning losses in fresh hams destined for PDO dry-cured ham production. Similarly, Schiavon et $a l .{ }^{9}$ found that the reduction in CP had little impact on raw ham characteristics, except for an increasing in ham subcutaneous fat covering and marbling scores.

The current experiment suggests that a LP diet has little overall influence on the chemical and physical profile of dry-cured ham, although the protein content and the protein: lipid ratio of the whole slice were lowered, and there was a tendency towards an increase in the lipid content with respect to the conventional diet. Previous work has already reported that feeding pigs with LP diets increases the proportion of fat in the carcass and in the meat ${ }^{22,23}$. These increases would depend on the replacement in the diets of some protein source with carbohydrates, which are more easily converted to fat ${ }^{24}$. However, the results of current experiment suggest that the response to LP diets would be at least partially dependent by the genetic background of the pig, as the Danbred pigs were less responsive of Anas one to the reduction of the dietary CP level.

Dietary CP reduction also tended to reduce the soluble protein content, but not the proteolysis index, and the values of the TBARS measured on the subcutaneous fat. The effect of these differences on the eating quality of the ham is unknown, and major research is required to clarify this. In any case, and in agreement with ${ }^{25}$, the differences in ham quality resulting from the use of LP diets seem very small, thereby confirming them as a valid strategy for sustainable production of dry-cured ham.

Pigs with different genetic backgrounds differ in growth rates, carcass composition, lean/fat ratios and adipose tissues characteristics ${ }^{4}$. As discussed in a companion paper ${ }^{9}$, the Danbred pigs used in the current experiment and fed restrictively exhibited greater feed efficiency (gain:feed, 0.271 vs. 0.269 ) and total carcass lean cuts (54.4 vs. $52.1 \mathrm{~kg} / 100 \mathrm{~kg}$ carcass), and thinner carcass back-fat cover (30.2 vs. $34.1 \mathrm{~mm})$ than the Anas pigs, but had the same average daily gain $(0.703 v s .0 .700 \mathrm{~kg} / \mathrm{d})$. Furthermore, the fresh hams obtained from the Danbred pigs were $6 \%$ heavier with $22 \%$ less fat cover thickness and a $42 \%$ greater marbling score than the Anas pigs. These data show that when kept under the same feeding and rearing conditions the two breeds have different levels of leanness. The results were consistent with previous studies in which Danbred pigs were compared with the traditional genotypes used to produce Italian dry-cured hams ${ }^{8,18}$. Vitale et al. ${ }^{18}$ found that the thighs from Danbred were heavier but had lower fat thickness and seasoning aptitude, with losses greater than $30 \%$, compared with other traditional breeds or commercial lines.

It is generally agreed that raw hams from lean pig genotypes are less suitable for the production of dry-cured hams because leaner carcasses and thinner subcutaneous fat cover are frequently associated with high seasoning losses, high salt absorption, increased dehydration and hardening of the meat, and the development of a salty flavour ${ }^{26}$. For these reasons, the consortia for the protection of PDO dry-cured hams restrict the breeds that can be used as boar line in the crossbreeding schemes aimed to originate heavy pigs for traditional dry-cured ham production. Italian Large White, Italian Landrace and Italian Duroc boars are always compliant with PDO dry-cured ham production, while several other breeds or genetic lines can be used as sires only if they originate from selection schemes having purposes consistent with those of this type of production ${ }^{6}$. 


\begin{tabular}{|c|c|c|c|c|c|c|c|c|c|c|c|c|c|}
\hline & \multicolumn{4}{|l|}{ Diet (D) } & \multicolumn{4}{|c|}{ Breeds (BR) } & \multicolumn{4}{|c|}{ Tissue (T) } & \multirow{2}{*}{\begin{tabular}{|l|}
$\mathrm{BR} \times \mathrm{D}$ \\
$\boldsymbol{P}$
\end{tabular}} \\
\hline & CONV & LP & SEM & $P$ & Anas & Danbred & SEM & $P$ & IM & SC & SEM & $P$ & \\
\hline \multicolumn{14}{|l|}{ Satured fatty acids (SFA) \% } \\
\hline 10:0 & 0.17 & \begin{tabular}{|l|l|}
0.17 \\
\end{tabular} & 0.004 & 0.37 & 0.18 & 0.16 & 0.004 & 0.015 & \begin{tabular}{|l|l|}
0.19 \\
\end{tabular} & 0.14 & 0.004 & $<0.001$ & 0.93 \\
\hline $12: 0^{\mathrm{a}}$ & 0.13 & 0.12 & 0.005 & 0.24 & 0.13 & 0.12 & 0.003 & 0.010 & 0.12 & 0.12 & 0.003 & 0.020 & 0.35 \\
\hline $14: 0^{\mathrm{b}}$ & 1.57 & 1.51 & 0.003 & 0.19 & 1.61 & 1.47 & 0.03 & 0.11 & 1.52 & 1.56 & 0.02 & $<0.001$ & 0.63 \\
\hline $16: 0$ & 21.4 & 21.5 & 0.28 & 0.99 & 21.9 & 20.9 & 0.21 & 0.69 & 20.8 & 21.4 & 0.16 & $<0.001$ & 0.80 \\
\hline $17: 0$ & 0.23 & 0.22 & 0.01 & 0.08 & 0.20 & 0.25 & 0.01 & $<0.001$ & 0.23 & 0.22 & 0.01 & 0.63 & 0.06 \\
\hline 18:0 & 8.79 & 9.09 & 0.12 & 0.06 & 8.96 & 8.88 & 0.12 & 0.64 & 9.18 & 8.66 & 0.12 & 0.003 & 0.009 \\
\hline $20: 0$ & 0.10 & 0.10 & 0.003 & 0.62 & 0.11 & 0.10 & 0.003 & 0.012 & 0.11 & 0.10 & 0.003 & 0.007 & 0.08 \\
\hline Total SFA & 30.8 & 33.1 & 0.71 & 0.19 & 32.6 & 32.1 & 0.72 & 0.52 & 32.5 & 32.2 & 0.44 & 0.52 & 0.69 \\
\hline \multicolumn{14}{|c|}{ Monounsatured fatty acids (MUFA) \% } \\
\hline $16: 1$ cis- $7^{c}$ & 0.39 & 0.38 & 0.01 & 0.43 & 0.35 & 0.42 & 0.01 & $<0.001$ & 0.38 & 0.39 & 0.01 & 0.29 & 0.95 \\
\hline $16: 1$ cis- 9 & 2.96 & \begin{tabular}{|l|}
2.78 \\
\end{tabular} & \begin{tabular}{|l|}
0.07 \\
\end{tabular} & 0.09 & 2.86 & 2.87 & 0.07 & 0.88 & \begin{tabular}{|l|l|}
3.05 \\
\end{tabular} & 2.69 & 0.05 & $<0.001$ & 0.51 \\
\hline $17: 1$ cis- $10^{\mathrm{d}}$ & 0.26 & \begin{tabular}{|l|l|}
0.24 \\
\end{tabular} & 0.01 & 0.10 & 0.23 & 0.27 & 0.01 & 0.009 & \begin{tabular}{|l|l|}
0.21 \\
\end{tabular} & 0.29 & 0.001 & $<0.001$ & 0.54 \\
\hline $18: 1$ cis-9 & 41.9 & 42.0 & 0.33 & 0.74 & 42.4 & 41.5 & 0.33 & 0.12 & 40.9 & 43.1 & 0.33 & $<0.001$ & 0.82 \\
\hline $18: 1$ cis- 11 & 4.18 & \begin{tabular}{|l|l|}
4.11 \\
\end{tabular} & 0.09 & 0.57 & 4.09 & 4.20 & 0.09 & 0.37 & \begin{tabular}{|l|l|}
4.11 \\
\end{tabular} & 4.18 & 0.09 & 0.59 & 0.07 \\
\hline $18: 1$ isomers $^{\mathrm{e}}$ & 0.32 & 0.31 & 0.01 & 0.60 & 0.32 & 0.32 & 0.01 & 0.96 & 0.28 & 0.35 & 0.01 & $<0.001$ & 0.44 \\
\hline $20: 1$ trans- $11^{f}$ & 0.80 & 0.76 & 0.03 & 0.46 & 0.81 & 0.76 & 0.03 & 0.39 & 0.70 & $\mid 0.87$ & 0.03 & 0.001 & 0.38 \\
\hline Total MUFA & 51.0 & \begin{tabular}{|l|}
50.8 \\
\end{tabular} & 0.33 & 0.75 & 51.4 & 50.4 & 0.33 & 0.12 & \begin{tabular}{|l|}
49.9 \\
\end{tabular} & 52.0 & 0.34 & $<0.001$ & 0.53 \\
\hline \multicolumn{14}{|c|}{ Polyunsatured fatty acids (PUFA) \% } \\
\hline $18: 2$ cis- 9 , cis- 12 & 13.8 & 13.5 & 0.19 & 0.33 & 13.1 & 14.2 & 0.19 & $<0.001$ & 14.0 & 13.2 & 0.16 & $<0.001$ & 0.83 \\
\hline $18: 2$ trans -9, trans -12 & 0.14 & 0.14 & 0.02 & 0.90 & 0.13 & 0.16 & 0.02 & 0.21 & 0.22 & 0.06 & 0.02 & $<0.001$ & 0.74 \\
\hline $18: 2$ other isomers $^{\mathrm{g}}$ & 0.18 & 0.17 & 0.01 & 0.15 & 0.18 & 0.17 & 0.01 & 0.75 & 0.22 & 0.14 & 0.01 & $<0.001$ & 0.21 \\
\hline $18: 3$ cis- 9 , cis- 12 , cis- 15 & 0.69 & 0.67 & 0.01 & 0.14 & 0.64 & 0.72 & 0.01 & $<0.001$ & 0.65 & 0.71 & 0.01 & $<0.001$ & 0.79 \\
\hline CLA sum & 0.12 & 0.12 & 0.004 & 0.43 & 0.11 & 0.13 & 0.005 & 0.028 & 0.13 & 0.11 & 0.01 & $<0.001$ & 0.26 \\
\hline $20: 2$ cis- 11, cis- 14 & 0.65 & 0.62 & 0.02 & 0.41 & 0.61 & 0.66 & 0.02 & 0.13 & 0.59 & 0.68 & 0.004 & $<0.001$ & 0.23 \\
\hline $20: 3$ cis- 8, cis- 11, cis- 14 & 0.18 & \begin{tabular}{|l|l|}
0.17 \\
\end{tabular} & 0.01 & 0.32 & 0.18 & 0.17 & 0.01 & 0.95 & 0.24 & 0.11 & 0.02 & $<0.001$ & 0.34 \\
\hline $20: 3$ cis- 11 , cis- 14 , cis- 17 & 0.14 & 0.12 & 0.01 & 0.07 & 0.11 & 0.13 & 0.01 & 0.64 & 0.13 & 0.13 & 0.01 & 0.77 & 0.92 \\
\hline $20: 4$ cis- 5 , cis- 8 , cis- 11, cis- $14^{\mathrm{h}}$ & 0.78 & 0.76 & 0.02 & 0.64 & 0.76 & 0.78 & 0.02 & 0.53 & 1.36 & 0.18 & 0.02 & $<0.001$ & 0.51 \\
\hline Total PUFA & 16.8 & 16.4 & 0.22 & 0.21 & 15.9 & 17.2 & 0.22 & $<0.001$ & 17.7 & 15.4 & 0.18 & $<0.001$ & 0.95 \\
\hline$n-3$ fatty acids ${ }^{\mathrm{i}}$ & 1.54 & 1.49 & 0.03 & 0.21 & 1.47 & 1.55 & 0.03 & 0.09 & 2.08 & 0.95 & 0.03 & $<0.001$ & 0.93 \\
\hline$n-6$ fatty acids & 15.0 & 14.7 & 0.16 & 0.25 & 14.2 & 15.5 & 0.20 & $<0.001$ & 15.4 & 14.4 & 0.16 & $<0.001$ & 0.97 \\
\hline$n-6 / n-3$ & 11.1 & 11.5 & 0.14 & 0.14 & 11.1 & 11.5 & 0.25 & 0.10 & \begin{tabular}{|l|l|}
7.46 \\
\end{tabular} & 15.1 & 0.14 & $<0.001$ & 0.78 \\
\hline Minor fatty acids $^{j}$ & 0.86 & \begin{tabular}{|l|}
0.78 \\
\end{tabular} & 0.03 & 0.09 & 0.80 & 0.84 & 0.03 & 0.37 & \begin{tabular}{|l|}
0.85 \\
\end{tabular} & 0.79 & 0.03 & 0.047 & 0.64 \\
\hline
\end{tabular}

Table 4. Fatty acid compositions of the intramuscular (IM) and subcutaneous (SC) fat of dry-cured hams obtained from pigs of different breeds (BR) and sex fed on conventional (CONV) or low protein (LP) diets. ${ }^{\mathrm{a}} \mathrm{C} 12: 0$ was 0.12 for barrows and 0.13 for gilts $(P=0.035$; $\mathrm{SEM}=0.03)$. ${ }^{\mathrm{b}}$ The $P$ value of the $\mathrm{BR} \times \mathrm{T}$ interaction was $0.019 .{ }^{\circ} \mathrm{C} 16: 1$ cis- 7 was 0.37 for barrows and 0.40 for gilts $(P<0.001 ; \mathrm{SEM}=0.008)$. ${ }^{\mathrm{d}}$ The $P$ value of the $\mathrm{D} \times \mathrm{T}$ interaction was 0.032 . ${ }^{\mathrm{e}}$ The $P$ value of the $\mathrm{D} \times \mathrm{T}$ interaction was 0.033 . ${ }^{\mathrm{f}} \mathrm{C} 20: 1$ trans- 11 was 0.72 for barrows and 0.85 for gilts $(P=0.014$; SEM $=0.03)$. ${ }^{\mathrm{g}}$ The $P$ value of the $\mathrm{D} \times \mathrm{T}$ interaction was 0.013 . ${ }^{\mathrm{h}} \mathrm{C} 20: 4$ cis5 , cis- 11 , cis- 14 were 0.83 for barrows and 0.72 for gilts $(P=0.002 ; \mathrm{SEM}=0.02) .{ }^{\mathrm{i}} n-3$ fatty acids were 1.56 for barrows and 1.47 for gilts $(P=0.002 ; \mathrm{SEM}=0.03) .{ }^{\mathrm{j}}$ Minor fatty acids include: $\mathrm{C} 6: 0$; C8:0; C10:1 cis-9; C11:0; C13:0; C14:1 cis-9; C15:0; C15:1 cis-10; C16:0 iso; C16:0 anteiso; C17:0 iso; C17:0 anteiso; C18:0 iso; C18:0 anteiso; C18:3 cis-6, cis-9, cis-12; C19:0; C21:0; C20:5 n-3; C22:0; C22:1 trans-13; C22:2 cis-13, cis-16, C23:0, C24:0; C24:1 cis-15, C22:6 cis-4, cis-7, cis-10, cis-13, cis-16, cis-19.

High fat cover and high intramuscular fat content of the ham are a barrier to water and salt penetration ${ }^{4,27}$. Seasoning losses in ham are known to be inversely related to the depth of fat cover ${ }^{10}$, which, in turn, is related to the depth of back-fat at the loin ${ }^{28}$. Rapid desiccation can also cause a crust to form on the surface, and once this has occurred, further diffusion of water is difficult so that the inner part of the ham becomes soft ${ }^{1}$. In the current experiment, and in line with expectations, seasoning losses were $4 \%$ higher in the Danbred than in the Anas hams, reflecting the leaner characteristics of the former breed. Despite the initial weight differences, at the end of seasoning the ham weight of the two breeds did not differ. In addition, at the end of seasoning, the lipid and the protein content of the ham lean part did not differ in the two breeds, but the Danbred ham still tended to be $5 \%$ richer in protein and $10 \%$ poorer in lipid than that from the Anas pigs, reflecting the different fat cover of the hams produced by the two breeds. This result was consistent with the values of fat thickness measured on the fresh hams. The fatty acid profiles of the various fatty depots in the ham showed there to be an $8 \%$ greater proportion of polyunsaturated fatty acid in the Danbred than in the Anas hams, consistent with the observation that a reduction in back-fat thickness is associated with an increase in the proportion of polyunsaturated fatty acid ${ }^{8}$. 
Salt confers a salty flavour to the meat and diminishes the health properties of the ham ${ }^{29,30}$. Moreover, it plays an important role, in conjunction with lower water activity, in microbial inhibition ${ }^{31}$. The negative relationship between meat salt content and the proteolysis index found in the current experiment confirmed the anti-proteolytic properties of salt ${ }^{32}$. The salt content of the lean was also negatively related to water activity and positively related to seasoning losses.

Surprisingly, despite notable differences in fresh ham weight, the quantity and quality of fat, and seasoning losses, there were only small differences between the hams of the two breeds in other quality traits, such as salt content, soluble protein, proteolysis index, TBARS measured in the muscle and the adipose tissue, and physical and texture characteristics. The relationships between ham fat thickness and these quality traits, including the salt content, were small. The small correlation between fresh ham fat thickness, salt content and the other quality traits may be partly due to the small number of hams examined in the current experiment and the high degree of variation in some variables. Further experiments with a greater number of dry-cured hams are, therefore, needed.

In conclusion, there is potential to use LP diets in the Italian PDO dry-cured ham production as it reduces the $\mathrm{N}$ release into the environment but has little influence on several chemical and physical attributes of the hams. This study also provides evidence that hams originated from pigs of breeds characterized by different potentials for lean growth may differ for raw ham fat cover and seasoning losses, whereas differences in several specific chemical, physical and textural attributes of the dry-cured hams are less evident. Further researches are needed to investigate the influence of these factors on the sensory and eating properties of dry-cured hams.

\section{Methods}

Ethics statement. All experimental procedures were reviewed and approved (\# 29562/2012) by the Ethical Committee for the Care and Use of Experimental Animals (CEASA) of the University of Padua, Italy. All the procedures and methods were completed in agreement with the Guideline for the Care and Use of Agricultural Animals in Agricultural Research and Teaching ${ }^{33}$.

Dry-cured hams origin and experimental design. This study used 40 dry-cured hams originated from a previous feeding trial, and details of the animals, diets, growth performances, and raw ham characteristics can be found in that paper ${ }^{9}$. Briefly, the feeding trial involved 96 pigs of four breeds fed restrictively CONV or LP feeds from 89 to $165 \mathrm{~kg} \mathrm{BW}$, according to the rules of PDO dry-cured ham production ${ }^{6,34}$. The CONV feeds contained 147 and $132 \mathrm{~g} / \mathrm{kg}$ of CP and 6.0 and $4.4 \mathrm{~g} / \mathrm{kg}$ of standardized ileal digestible (SID) lysine (Lys) in the early (89-120 kg BW) and late (121-165 kg BW) finishing periods, respectively. The LP diets contained only 119 and $103 \mathrm{~g} / \mathrm{kg}$ of CP and 4.8 and $3.5 \mathrm{~g} / \mathrm{kg}$ of SID Lys in the early and late finishing periods, respectively, whereas the energy content was the same in the two feeding programs. After slaughtering and carcass dissection, all hams were sent to "Testa \& Molinaro" ham factory [San Daniele del Friuli (UD), Italy] to be processed into dry-cured hams in accordance with San Daniele procedures ${ }^{34}$. From these, 40 left dry-cured hams were randomly chosen among all the left hams of the trial, to equally represent the two CP contents, the two breeds, and the two sexes, according to a 2 breeds $\times 2$ dietary treatments $\times 2$ sexes factorial design with 5 replications for each combination.

Among the pig breeds used in the feeding trial, we selected for this study the two characterized by the largest differences in term of final back-fat thickness, carcass lean yield and fat cover thickness of the hams ${ }^{9}$, which reflected different aptitudes for lean growth when kept under restricted feeding regime. The "fatter" breed consisted of traditional cross between Italian Duroc boars (D) and Italian Large White (LW) sows selected by the Italian Pig Breeders Association (Anas) according to a breeding programme specifically intended for traditional heavy pig production, with a particular emphasis on ham quality traits ${ }^{35,36}$. The "leaner" breed consisted of pig progeny of commercial Danish Duroc (Danbred) boars mated to crossbred sows of their parent lines.

Dry-curing processing. After the carcass dissection, raw hams were refrigerated for 24 hours, moved to the ham factory, trimmed and weighed. Fat cover thickness was measured on raw hams with a ruler at the level of the Biceps femoris muscle below the femur head of the ham.

At the ham factory, the trimmed hams were salted with sea salt and stored at $2-3^{\circ} \mathrm{C}$ for the number of days corresponding to the weight in $\mathrm{kg}$ of each fresh ham ${ }^{37}$. After salting, the hams were weighed and salting losses calculated. The hams were then pressed for 48 hours to give hams the typical San Daniele guitar-like shape, and rested for 90 days at $70-80 \%$ relative air moisture and $4-6^{\circ} \mathrm{C}$. The hams were then rinsed with cold water, dried for one week, greased with a natural mixture made from lard, salt and cereal meal, ripened in a naturally ventilated room for 15 months, weighed, deboned and weighed again. Seasoning and deboning losses were measured.

Ham sampling. Just below the femur head the cued hams were cut to obtain three slices of different thicknesses. The first slice ( $15 \mathrm{~mm}$ thick) was used to evaluate water activity and thiobarbituric acid reactive substances (TBARS), reflecting secondary lipid oxidation products. The second slice ( $14 \mathrm{~mm}$ thick) was used for physical and texture analyses, after which the lean part was separated from the fat with a knife, minced and analysed for proximate composition, Na content and FA profile. The separated subcutaneous fat was analysed for FA composition. The third slice ( $3 \mathrm{~mm}$ thick) was ground and analysed for proximate composition of the whole slice including subcutaneous fat.

Analyses of water activity and secondary lipid oxidation products (TBARS). The water activity in the lean part of the ham was measured with a dew-point hygrometer (AquaLab 4 TEV, Decagon Devices, Pullman, WA, USA) on squared-shaped samples $(15 \times 15 \mathrm{~mm})$ taken from the part closest to the Biceps femoris muscle.

The lean part and the subcutaneous fat of the slice were separated with a knife and minced, then 2-gram samples of each part were analysed for TBARS ${ }^{38}$. After adding $5 \mathrm{ml}$ of $\mathrm{n}$-heptane and $8 \mathrm{ml}$ of trichloroacetic acid 5\%, 
the samples were homogenized for $30 \mathrm{~s}$ at minimum speed using a rod homogenizer (T25 Digital Ultra-Turrax, Ika, Staufen, Germany). Following centrifugation $\left(2834 \mathrm{~g}\right.$ for $3 \mathrm{~min}$ at $\left.4{ }^{\circ} \mathrm{C}\right)$ the supernatant was removed and $2.5 \mathrm{ml}$ of the lower layer was filtered and mixed with $2.5 \mathrm{ml}$ of thiobarbituric acid $(0.02 \mathrm{M})$ in Pyrex test tubes. The solution was incubated in a Falc SB24 thermostatically-controlled water bath (Falc Instruments, Treviglio, Bergamo, Italy) at $95^{\circ} \mathrm{C}$ for $35 \mathrm{~min}$ then cooled with running water. The absorbance of the chromatic complex was measured at $532 \mathrm{~nm}$ using a UV-Vis spectrophotometer (V-750, Jasco Europe, Cremella, Lecco, Italy) and expressed as milligrams of malondialdehyde $/ \mathrm{kg}$ of sample using a calibration curve made with solutions of 1,1,3,3-Tetramethoxypropane at scalar concentrations (Sigma-Aldrich, Saint Louis, Missouri, USA).

Physical and texture analyses. Physical and texture analyses were performed on the four muscles of each slice (Biceps femoris (Bf), Quadriceps femoris (Qf), Semimembranosus (Sm), and Semitendinosus (St), (Fig. 5). The lightness $\left(\mathrm{L}^{*}\right)$, green-red $\left(\mathrm{a}^{*}\right)$ and blue-yellow $\left(\mathrm{b}^{*}\right)$ components of each muscle were assessed with a Minolta CM-500 colorimeter (Minolta, Osaka, Japan) with $10^{\circ}$ standard observer, D65 illuminant and an aperture of $8 \mathrm{~mm}$, according to $\mathrm{CIE}^{39}$. The $\mathrm{pH}$ was measured on the 4 muscles with a Crison Basic $20 \mathrm{pH}$ meter (Crison SpA, Carpi, Modena, Italy).

The texture profile (TPA) was analysed with a TA.XT plus Texture Analyser (Stable Micro Systems, London, $\mathrm{UK}$ ) at $15^{\circ} \mathrm{C}$ with a $500 \mathrm{~N}$ load cell and a $20 \mathrm{~mm}$ compression probe. Each of the four muscles was compressed twice to $30 \%$ of its original thickness $(14 \mathrm{~mm}$ ) at a speed of $2 \mathrm{~mm} / \mathrm{s}$. The Texture Exponent software (Stable Micro System, London, UK) was used to compute the hardness, cohesiveness, adhesiveness, springiness and chewiness of each muscle from the two compression curves, according to Tabilo et al. ${ }^{40}$. Hardness $(\mathrm{N})$ was defined as the maximum peak force, which is the force needed to obtain deformation. Cohesiveness (dimensionless) was defined as the ratio between the area under the second curve and the area under the first curve. Adhesiveness $(\mathrm{N} \times \mathrm{s})$ was the negative area between the two curves, which represents the work needed to overcome the attractive forces between the compression device and the muscle surface. Springiness (dimensionless) was the ratio of the time recorded between the start of the second area and the second probe reversal to the time recorded between the start of the first area and the first probe reversal, which represents the elasticity of the muscle. Chewiness $(\mathrm{N})$ was calculated as hardness $\times$ cohesiveness $\times$ springiness.

Shear force was measured with a Warner-Bratzler texture analyser (LS5, Ametek Lloyd Instruments, Fareham, UK) equipped with an inverted V-shaped shear blade. Five $1-\mathrm{cm}^{3}$ prisms per muscle were obtained from each sample and cut with a force of $500 \mathrm{~N}$ and a speed of $2 \mathrm{~mm} / \mathrm{s}$. Shear force was then calculated with the NEXIGEN Plus 3 software (Bognor Regis, UK).

Chemical analyses. The proximate composition, determined both on the whole slice and on the "lean" part of the slice only (the ham slice without subcutaneous fat), concerned moisture (\#950.46), total protein $\mathrm{N} \times 6.25$ (\# 981.10), lipids (\#991.36) and ash (\# 920.153), according to $\mathrm{AOAC}^{41}$. The soluble $\mathrm{N}$, determined in trichloroacetic acid $10 \%$ solution $^{42}$ and expressed as soluble protein (soluble $\mathrm{N} \times 6.25$,), and the proteolysis index, calculated as the percentage ratio between the soluble and total protein, were determined on the lean part of the slice only. Also, $\mathrm{Na}$ was determined on the lean part of the slice, using an inductively coupled plasma - optical emissions spectrometer (ICP-OES; Ciros Vision EOP, Spectro Analytical Instruments GmbH, Kleve, Germany) on an aliquot of $1 \mathrm{~g}$ of the minced slice, which was mixed with $7 \mathrm{ml}$ of $67 \%$ nitric acid and $2 \mathrm{ml}$ of $30 \%$ hydrogen peroxide and mineralized at $200^{\circ} \mathrm{C}$ for $15-18 \mathrm{~min}$ in a microwave digestion system (Milestone Start, Sorisole, Bergamo, Italy). The samples were cooled to $35^{\circ} \mathrm{C}$ and made up to volume with distilled water. Salt was calculated as $\mathrm{Na} \times 2.50^{43}$.

According to Dalla Bona et al. ${ }^{44}$ and Schafer ${ }^{45}$, fat was extracted from both the subcutaneous depot (SC) and from the lean part of the slice (intramuscular, IM). IM and SC fat were ground separately and homogenized for $10 \mathrm{~s}$ at $4500 \mathrm{~g}$ (Grindomix GM200; Retsch, Haan, Düsseldorf, Germany). A sub-sample of 20 to $30 \mathrm{~g}$ was stored at $-20^{\circ} \mathrm{C}$ until analysis. After thawing at ambient temperature, the fat was extracted from a $4.0 \mathrm{~g}$ subsample of each part mixed with $15 \mathrm{~g}$ of anhydrous sodium sulphate. The mixture was homogenized with a Hydromatrix (Phenomenex, Castel Maggiore, Bologna, Italy) and transferred to 15-mL stainless steel extraction cells for accelerated solvent extraction (ASE, Thermo Fisher Scientific Inc., Waltham, MA, USA) with petroleum ether as the solvent. The extraction conditions were: temperature, $120^{\circ} \mathrm{C}$; pressure, $10 \mathrm{MPa}$; three static cycles of $1 \mathrm{~min}$ each; rinse, $100 \%$; purge, $60 \mathrm{~s}$ using $8 \mathrm{~mL} /$ sample of fresh solvent ${ }^{46}$. The solvent was evaporated using a rotary film evaporator (Rotavapor ${ }^{\circledR}$ R-205, Buchi Italia s.r.l., Cornaredo, Italy) and samples were placed in an oven at $60^{\circ} \mathrm{C}$ for $15 \mathrm{~min}$ before being weighed. An aliquot of $40 \mathrm{mg}$ of extracted fat was collected to be methylated according to Christie $^{47}$, with minor modifications. Fat samples were transferred to a test tube fitted with a condenser, to which was added $2 \mathrm{~mL}$ of $2 \%$ sulphuric acid in methanol.

According to Gallo et al. ${ }^{15}$, the mixture was left overnight in a stoppered tube at $50{ }^{\circ} \mathrm{C}$, then $2 \mathrm{ml}$ of n-heptane and water $(4 \mathrm{~mL})$ containing potassium bicarbonate $(2 \%)$ was added. Samples were centrifuged at $2834 \mathrm{~g}$ for $10 \mathrm{~min}$, the supernatant was collected with a micropipette and transferred to a vial for gas chromatographic (GC) analysis. The fatty acid (FA) methyl ester contents were determined with an Agilent 7820 GC system (Agilent, Palo Alto, CA, USA) equipped with a flame-ionization detector and an Omegawax 250 capillary column (Omegawax 250, Supelco, Bellefonte, PA, USA; $30 \mathrm{~m}, 0.25 \mathrm{~mm}$ i.d.; film thickness $0.25 \mu \mathrm{m}$ ). The carrier gas was hydrogen at a flow rate of $1 \mathrm{~mL}$ min-1.

The GC operative conditions were those described by Dalla Bona ${ }^{44}$. Briefly, a split/splitless injector with a split ratio of 1:80 was used to inject an aliquot of the sample into the GC system under the following conditions: initial oven temperature $60^{\circ} \mathrm{C}$ held for $1 \mathrm{~min}$, then increased to $173^{\circ} \mathrm{C}$ at a rate of $2^{\circ} \mathrm{C} / \mathrm{min}$ and held for $30 \mathrm{~min}$, then increased to $185^{\circ} \mathrm{C}$ at $1^{\circ} \mathrm{C} / \mathrm{min}$ and held for $5 \mathrm{~min}$, and finally increased to $220^{\circ} \mathrm{C}$ at a rate of $3^{\circ} \mathrm{C} / \mathrm{min}$ and held for $19 \mathrm{~min}$. The injector temperature was set at $270^{\circ} \mathrm{C}$ and the detector temperature at $300^{\circ} \mathrm{C}$. Individual FA methyl esters were identified by comparison with a standard mixture (18918-1AMP 595 N, Supelco, Bellefonte, 
PA, USA). The FA methyl esters were quantified using methyl 12-tridecenoate as internal standard, and the area of each peak was corrected using flame ionization detector (FID) relative response factors. These response factors were determined using calibrations obtained from five serial dilutions for each standard fatty acid ${ }^{46}$. All calibrations were linear and all $\mathrm{R}^{2}$ were $>0.998$. The FA composition was expressed as grams per $100 \mathrm{~g}$ of total FAs.

Statistical analysis. Traits with one observation per ham (weights and weight losses during processing, and salt content, soluble protein, proteolysis index, water activity, and TBARS of lean part of the slice) were analysed according to a linear model which included the fixed effects of breed, sex and diet and their interactions.

All the other traits, which presented replications per ham because determined on different muscles (physical and texture traits) or tissues (proximate composition and FA profile), were processed using the SAS MIXED procedure (SAS Inst. Inc., Cary, NC) according to the following linear mixed model:

$$
\begin{aligned}
\mathrm{y}_{\mathrm{ijklm}}= & \mu+\mathrm{BR}_{\mathrm{i}}+\text { diet }_{\mathrm{j}}+\text { tissue }_{\mathrm{k}}+\text { sex }_{\mathrm{l}}+\mathrm{BR} \times \text { diet }_{\mathrm{ij}}+\mathrm{BR} \times \text { tissue }_{\mathrm{ik}} \\
& +\operatorname{diet} \times \text { tissue }_{\mathrm{jk}}+\mathrm{BR} \times \operatorname{diet} \\
& \times \text { tissue }_{\mathrm{ijk}}+\operatorname{ham}(\mathrm{BR} \times \operatorname{diet} \times \operatorname{sex})_{m: \mathrm{ijl}}+\mathrm{e}_{\mathrm{ijklm}}
\end{aligned}
$$

where $y_{i j k l m}$ is the observed trait; $\mu$ is the overall intercept of the model; $B R_{i}$ is the fixed effect of the ith breed $(i=1,2)$; diet $t_{j}$ is the fixed effect of the $j$ th feeding treatment $(j=1,2)$; tissue $_{k}$ is the fixed effect of the kth muscle $(\mathrm{k}=1, \ldots, 4)$ or part of slice $(\mathrm{k}=1,2)$; $\operatorname{sex}_{1}$ is the fixed effect of the lth gender $(\mathrm{l}=1,2 ;[1=$ barrow, $2=$ gilt $])$; $\mathrm{BR} \times$ diet $_{\mathrm{ij}}$ is the effect of the interaction between breed and diet; $\mathrm{BR} \times \mathrm{tissue}_{\mathrm{ik}}$ is the effect of the interaction between breed and muscle or part of slice; diet $\times$ tissue $_{j \mathrm{k}}$ is the effect of the interaction between diet and muscle or part of slice; $\mathrm{BR} \times$ diet $\times$ tissue $_{\mathrm{ijk}}$ is the effect of the interactions among breed, diet and muscle or part of slice; ham $_{\mathrm{m}: \mathrm{ijl}}$ is the random effect of the $\mathrm{m}^{\text {th }}$ ham $(\mathrm{m}=1, \ldots, 40)$ within $\mathrm{BR}$, diet and sex; $\mathrm{e}_{\mathrm{ijklm}}$ is the random residual.

Ham within BR, diet and sex, and residuals were assumed to be independently and normally distributed with a mean of zero and variances of $\sigma_{\text {ham }}{ }^{2}$ and $\sigma_{e}^{2}$, respectively. In line with the experimental design, the effects of BR, diet, sex and $\mathrm{BR} \times$ diet were tested using ham within the $\mathrm{BR} \times$ diet $\times$ sex interaction as the error line, whereas the effects of tissue and its interactions were tested on the random residual, according to model used in Schiavon et al. ${ }^{48}$.

The 4 degrees of freedom of $\mathrm{BR} \times \operatorname{diet}_{\mathrm{ij}}$ interaction were used to test the significance of the differences due

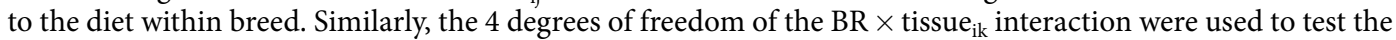
significances of the differences due to $\mathrm{BR}$ in the chemical compositions of both the whole slice and the lean part of it. Differences among muscles for $\mathrm{pH}$, colour and the texture variables were compared using the Bonferroni correction for multiple testing.

Received: 8 January 2019; Accepted: 30 November 2019;

Published online: 13 December 2019

\section{References}

1. Toldrá, F. \& Aristoy, M. C. Dry cured ham. In: F. Toldrá editor. Handbook of meat processing. Ames, Iowa: Blackwell Publishing; 2010. p. 351-362.

2. European Commission (EC). Food safety and quality. Quality labels. In: Food and agricultural products (DOOR database). European Commission. 2015. http://ec.europa.eu/agriculture/quality/door/list.html. Accessed 15 May 2018.

3. Bermúdez, R., Franco, D., Carballo, J. \& Lorenzo, J. M. Physicochemical changes during manufacture and final sensory characteristics of dry-cured Celta ham. Effect of muscle type. Food Contr. 43, 263-269 (2014).

4. Čandek-Potokar, M. \& Škrlep, M. Factors in pig production that impact the quality of dry-cured ham: a review. Anim. 6, 327-338 (2012).

5. Laureati, M. et al. Characterization and differentiation of Italian Parma, San Daniele and Toscano dry-cured hams: A multidisciplinary approach. Meat Sci. 96, 288-94 (2014).

6. Bosi, P. \& Russo, V. The production of the heavy pig for high quality processed products. Ital. J. Anim. Sci. 3, 309-321 (2004).

7. Pagliarini, E. et al. Influence of pig genetic type on sensory properties and consumer acceptance of Parma, San Daniele and Toscano dry-cured hams. J. Sci. Food Agric. 96, 798-806 (2016).

8. Lo Fiego, D. P., Santoro, P., Macchioni, P. \& De Leonibus, E. Influence of genetic type, live weight at slaughter and carcass fatness on fatty acid composition of subcutaneous adipose tissue of raw ham in the heavy pig. Meat Sci. 69, 107-114 (2005).

9. Schiavon, S. et al. Growth performance, and carcass and raw ham quality of crossbred heavy pigs from four genetic groups fed low protein diets for dry-cured ham production. Anim. Feed Sci. Technol. 208, 170-181 (2015).

10. Gou, P., Guerrero, L. \& Arnau, J. Sex and crossbreed effects on the characteristics of dry-cured ham. Meat Sci. 40, 21-31 (1995).

11. Peloso, J. V., Lopes, P. S., Gomide, L. A. M., Guimarães, S. E. F. \& Carneiro, P. L. S. Carcass and ham quality characteristics of heavy pigs from different genetic groups intended for the production of dry-cured hams. Meat Sci. 86, 371-376 (2010).

12. Rodríguez-Sánchez, J. A. et al. The influence of dietary lysine restriction during the finishing period on growth performance and carcass, meat, and fat characteristics of barrows and gilts intended for dry-cured ham production. J. Anim. Sci. 89, 3651-3662 (2011).

13. Schiavon, S. et al. Effects of feed allowance and indispensable amino acid reduction on feed intake, growth performance and carcass characteristics of growing pigs. PLoS ONE 13, e0195645 (2018).

14. Wang, T. et al. Effects of dietary lysine level on the content and fatty acid composition of intramuscular fat in late-stage finishing pigs. Can. J. Anim. Sci. 98, 241-249 (2018).

15. Gallo, L. et al. Effect of progressive reduction in crude protein and lysine of heavy pigs diets on some technological properties of green hams destined for PDO dry-cured ham production. Meat Sci. 121, 135-140 (2016).

16. Suárez-Belloch, J., Latorre, M. A. \& Guada, J. A. The effect of protein restriction during the growing period on carcass, meat and fat quality of heavy barrows and gilts. Meat Sci. 112, 16-23 (2016).

17. Carrapiso, A. I. \& García, C. Effect of the Iberian pig line on dry-cured ham characteristics. Meat Sci. 80, 529-53416 (2008).

18. Vitale, M., Corazzin, M., Favotto, S., Saccà, E. \& Piasentier, E. Variability in the characteristics of fresh meat and thighs in relationship to genetic type of the heavy pig. Ital. J. Anim. Sci. 8, 561-563 (2008).

19. Canh, T. T. et al. Dietary protein affects nitrogen excretion and ammonia emission from slurry of growing-finishing pigs. Livest. Prod. Sci. 56, 181-191 (1998). 
20. Gallo, L. et al. Growth performance of heavy pigs fed restrictively diets with decreasing crude protein and indispensable amino acids content. Livest. Sci. 161, 130-138 (2014).

21. Gallo, L. et al. Carcass quality and uniformity of heavy pigs fed restrictive diets with progressive reductions in crude protein and indispensable amino acids. Livest. Sci. 172, 50-58 (2015).

22. Lambe, N. R. et al. Effects of low protein diets on pigs with a lean genotype 2. Compositional traits measured with computed tomography (CT). Meat Sci. 95, 129-136 (2013).

23. Wood, J. D. et al. Effects of low protein diets on pigs with a lean genotype. 1. Carcass composition measured by dissection and muscle fatty acid composition. Meat Sci. 95, 123-128 (2013).

24. Tous, N., Lizardo, R., Vilà, B. \& Gispert, M. Effect of reducing dietary protein and lysine on growth performance, carcass characteristics, intramuscular fat, and fatty acid profile of finishing barrows 1. J. Anim. Sci. 92, 129-140 (2014).

25. Grassi, S., Casiraghi, E., Benedetti, S. \& Alamprese, C. Effect of low-protein diets in heavy pigs on dry-cured ham quality characteristics. Meat Sci. 131, 152-157 (2017).

26. Ruiz-Carrascal, J., Ventanas, J., Cava, R., Andrés, A. I. \& García, C. Texture and appearance of dry cured ham as affected by fat content and fatty acid composition. Food Res. Intern. 33, 91-95 (2000).

27. Capraro, D., Buccioni, A., Piasentier, E. \& Spanghero, M. Feeding finishing heavy pigs with corn silages: effects on backfat fatty acid composition and ham weight losses during seasoning. Ital. J. Anim. Sci. 16, 588-592 (2017).

28. Cecchinato, A., Schiavon, S., Tagliapietra, F. \& Gallo, L. Relationships between in vivo measurements of backfat thickness and several carcass and ham traits in heavy pigs. Agric Conspec. Sci. 78, 255-258 (2013).

29. Jiménez-Colmenero, F., Ventanas, J. \& Toldrá, F. Nutritional composition of dry-cured ham and its role in a healthy diet. Meat Sci. 84, 585-593 (2010).

30. Ruusunen, M. \& Puolanne, E. Reducing sodium intake from meat products - a review. Meat Sci. 70, 531-541 (2005).

31. Blesa, E. et al. Microbiology and physico-chemical changes of dry-cured ham during the post-salting stage as affected by partial replacement of $\mathrm{NaCl}$ by other salts. Meat Sci. 78, 135-142 (2008).

32. Sárraga, C. Meat Proteinases and Their Relation With Curing. In: Smulders F. J. M., Toldrá F., Flores, J., Prieto, M. editors. New technologies for meat and meat products. Nijmegen, The Netherlands: Audet Tijdschriften BV. p. 233-246 (1992).

33. Consortium. Guide for the Care and Use of Agricultural Animals in Agricultural Research and Teaching. Consortium for Developing a Guide for the Care and Use of Agricultural Animals in Agricultural Research and Teaching, Champaign, IL (1988).

34. European Commission (EC). Prosciutto di San Daniele. Protected Designation of Origin. Publication pursuant to article 18/(2) of the commission regulation (EC) No. 1898/2006, in accordance with the article 17 of Council Regulation (EEC) No. 2081/92 of July, 14th 1992. Off. J. Eur. Commun. C188, 24-27 (2006).

35. Fontanesi, L. et al. A genome wide association study for backfat thickness in Italian Large White pigs highlights new regions affecting fat deposition including neuronal genes. BMC Genom. 13, 583 (2012).

36. Sturaro, E., Gallo, L., Noventa, M. \& Carnier, P. The genetic relationship between enzymatic activity of cathepsin B and firmness of dry-cured hams. Meat Sci. 79, 375-381 (2008).

37. Gaspardo, B., Procida, G., Toso, B. \& Stefanon, B. Determination of volatile compounds in San Daniele ham using headspace GC-MS. Meat Sci. 80, 204-209 (2008).

38. Botsoglou, N. A. et al. Rapid, Sensitive, and Specific Thiobarbituric Acid Method for Measuring Lipid Peroxidation in Animal Tissue, Food, and Feedstuff Samples. J. Agric. Food Chem. 42, 1931-1937 (1994).

39. CIE. Recommendations on uniform color spaces-color difference equations psychometric color terms. Paris: Commission International de L’Eclairage Supplement No. 2 to CIE Publication No. 15 (E-1.3.1) 1971/(TC-1.3) (1978).

40. Tabilo, G., Flores, M., Fiszman, S. M. \& Toldrá, F. Postmortem meat quality and sex affect textural properties and protein breakdown of dry-cured ham. Meat Sci. 51, 255-260 (1999).

41. International AOAC. Official Methods of Analysis. 19th ed. Gaithersburg: AOAC International (2012).

42. Careri, M. et al. Sensory property relationships to chemical data of Italian-type dry-cured ham. J. Food Sci. 58, 968-972 (1993).

43. European Union (EU). Regulation (EU) No. 1169/2011 of the European Parliament and of the Council of 25 October 2011. OffJ EU. 22/11/2011.

44. Dalla Bona, M., Schiavon, S., Carraro, L. \& Gallo, L. Growth performance, carcass traits and meat quality of growing pigs on different feeding regimes slaughtered at $145 \mathrm{~kg}$ BW. Ital. J. Anim. Sci. 15, 419-427 (2016).

45. Schäfer, K. Accelerated solvent extraction of lipids for determining the fatty acid composition of biological material. Anal. Chim. Acta 358, 69-77 (1998).

46. Schiavon, S. et al. The influence of different sample preparation procedures on the determination of fatty acid profiles of beef subcutaneous fat, liver and muscle by gas chromatography. J. Food Comp. Anal. 50, 10-18 (2016).

47. Christie, W. W. Preparation of Ester Derivatives of Fatty Acids for Chromatographic Analysis. In: Christie WW editor. Advances in Lipid Methodology - Two. Dundee, Scotland, United Kingdom: Oily Press. p. 69-111 (1993).

48. Schiavon, S., Bergamaschi, M., Pellattiero, E., Simonetto, A. \& Tagliapietra, F. Fatty acid composition of lamb liver, muscle, and adipose tissues in response to rumen-protected conjugated linoleic acid (CLA) supplementation is tissue depended. J. Agric. Food Chem. 65, 10604-10614 (2017).

\section{Acknowledgements}

The authors greatly appreciate the technical assistance of A. Simonetto and L. Carraro, all the herdsmen, and all the laboratory staff. Our grateful thanks to the Agricola Tre Valli of the Gruppo Veronesi for excellent collaboration and technical assistance. The Authors also thank M. Pasqualotto and G. Tonin for their support in the assessment of raw hams, and G. Cadel and M. Bassi (Regional Breeders Association of Friuli Venezia Giulia, AAFVG) for their support in pig retrieval. This study was supported by Progetto AGER (Italy) (Grant 2011-0280, and University of Padova (DOR1655405/16).

\section{Author contributions}

S.S. and L.G. conceived of this experiment. G.C., E.S., E.C., S.G., M.D.B. and E.N. gave substantial contributions to analytical procedures, statistical analysis, and the draft writing of the manuscript. S.S., L.G. and E.S. contributed in revising critically the manuscript. All authors read and approved the final manuscript.

\section{Competing interests}

The authors declare no competing interests.

\section{Additional information}

Correspondence and requests for materials should be addressed to S.S.

Reprints and permissions information is available at www.nature.com/reprints. 
Publisher's note Springer Nature remains neutral with regard to jurisdictional claims in published maps and institutional affiliations.

(c) (i) Open Access This article is licensed under a Creative Commons Attribution 4.0 International License, which permits use, sharing, adaptation, distribution and reproduction in any medium or format, as long as you give appropriate credit to the original author(s) and the source, provide a link to the Creative Commons license, and indicate if changes were made. The images or other third party material in this article are included in the article's Creative Commons license, unless indicated otherwise in a credit line to the material. If material is not included in the article's Creative Commons license and your intended use is not permitted by statutory regulation or exceeds the permitted use, you will need to obtain permission directly from the copyright holder. To view a copy of this license, visit http://creativecommons.org/licenses/by/4.0/.

(c) The Author(s) 2019 